\title{
Anesthesia for cesarean section and SARS Cov-2: Observational study in Peru
}

\section{Anestesia para cesárea en gestantes y SARS-CoV-2: estudio observacional en Perú}

\author{
Marleny Elizabeth Huayanay Bernabé (iD, Marjorie Lisseth Calderón Lozano iD, Álvaro Renato Moreno \\ Gonzáles iD, José Gunther Vásquez Rojas (iD \\ Instituto Nacional Materno Perinatal. Lima, Peru. \\ Correspondence: Instituto Nacional Materno Perinatal, Jr. Miroquesada 941. Cercado de Lima. Lima, Peru. E-mail: gunther176@hotmail.com
}

What do we know about this problem?

Information regarding the clinical behavior and the anesthetic and perioperative management of pregnant women with SARS-CoV-2 is starting to appear in the literature in the form of case reports and case series, although evidence and recommendations are still limited.

What does this study contribute that is new?

This study contributes to the knowledge of the clinical characteristics, results of anesthetic and perioperative management, complications and neonatal outcomes in seroprevalent pregnant women for SARS-CoV-2, delivered by cesarean section.

How to cite this article:

Huayanay Bernabé ME, Calderón Lozano ML, Moreno Conzáles ÁR, Vásquez Rojas JG. Anesthesia for cesarean section and SARS Cov-2: Observational study in Peru. Colombian Journal of Anesthesiology. 2021;49:e998.

\section{Abstract}

Introduction

Information regarding the clinical behavior and the anesthetic and perioperative management in pregnant patients with SARS-CoV-2 is starting to appear in the literature in the form of case reports or case series. However, strong evidence and recommendations are still limited.

\section{Objective}

To describe the clinical characteristics, the results of anesthetic and perioperative management, and complications in seroprevalent pregnant women for SARS-CoV-2 infection, delivered by cesarean section.

\section{Methodology}

Observational study in which 107 clinical records of pregnant women who were seroprevalent for SARS-CoV-2 infection were reviewed and analyzed between April and June, 2020. Demographic, clinical and serological data were collected, as well as data on the anesthetic technique and intraoperative and postoperative complications.

Results

Of the 107 pregnant women with SARS-CoV-2 infection, 99 (92.52\%) were asymptomatic and $8(7.48 \%)$ had mild symptoms. The most frequent reasons for cesarean section were cephalopelvic disproportion in $20(18.68 \%)$, previous cesarean section in $20(18.68 \%)$ and non-reassuring fetal status in 14 (13.08\%). Anesthesia technique was neuraxial in all cases, with spinal used in $100(93.5 \%)$, combined spinal-epidural in $4(3.7 \%)$ and epidural catheter in $3(2.8 \%)$ patients. No deaths had occurred until the third postoperative day of follow-up.

\section{Conclusions}

The majority of pregnant women with SARS-CoV-2 infection are asymptomatic. In this work, spinal, combined spinal-epidural and epidural neuroxial anesthesia techniques were shown to be effective and safe for these patients and their newborn babies.

\section{Keywords}

COVID-19, Neuraxial anesthesia; SARS-CoV-2; Pregnancy; Cesarean section. 


\section{Resumen}

Introducción

La información del comportamiento clínico, manejo anestésico y perioperatorio en gestantes con SARS-CoV-2 empieza a aparecer en la literatura mediante reportes de casos o serie de casos. Aún son limitadas la evidencia contundente y las recomendaciones.

\section{Objetivo}

Describir las características clínicas, resultados del manejo anestésico, perioperatorio y complicaciones en gestantes seroprevalentes para infección por SARS-CoV-2, cuyo parto fue por cesárea.

\section{Metodología}

Estudio observacional en el cual se revisaron y analizaron 107 historias clínicas de gestantes seroprevalentes para infección por SARS-CoV-2, de abril a junio del 2020. Se recolectaron datos demográficos, clínicos, serología, técnica anestésica y complicaciones intra-y postoperatorias.

\section{Resultados}

De las 107 gestantes con infección por SARS-CoV-2, 99 (92,52 \%) fueron asintomáticas y 8 (7,48\%) presentaron síntomas leves. Los motivos más frecuentes de cesárea fueron: desproporción céfalo-pélvica 20 (18,68\%), cesárea previa 20 (18,68\%) y estado fetal no tranquilizador 14 $(13,08 \%)$. La técnica anestésica fue neuro axial en su totalidad, espinal en 100 (93,5\%), combinada espinal-epidural en $4(3,7 \%)$ y epidural con catéter en $3(2,8 \%)$ pacientes. No se registraron muertes hasta el tercer día postoperatorio de seguimiento.

\section{Conclusiones}

Las gestantes con infección por SARS-CoV-2 presentan — en su mayoría—infecciones asintomáticas. En este trabajo, la anestesia neuro axial: espinal, combinada espinal-epidural y epidural, se presentan como técnicas efectivas y seguras para estas pacientes y sus recién nacidos.

\section{Palabras clave}

COVID-19, Anestesia neuro axial; SARS-CoV-2; Embarazo; Cesárea.

\section{INTRODUCTION}

The current COVID-19 pandemic declared by the World Health Organization on March 11, 2020, began in Wuhan, province of Hubei, China, in December 2019. The infection caused by the new SARS-CoV-2 coronavirus, spread quickly throughout China and the rest of the world, causing the disease and killing millions of people in its wake. Our country is among the most severely affected by this pandemic; as of the end of September 2020, official figures in Peru report more than 800,000 infected and more than 32,000 dead, the highest number of deaths for every one million people in Latin America, an among the highest in the world.

SARS-COV-2 has affected all population groups - the obstetric population not being the exception - posing great challenges to the healthcare profession, compounded by scant knowledge about this new disease. One of those challenges is, no doubt, the perioperative management of obstetric patients.
Physiological changes occurring during pregnancy, both in the immune and cardiorespiratory systems, as well as atelectasis from the mechanical effect of the pregnant uterus, reduced lung capacity and high oxygen consumption are reasons to believe that obstetric patients will respond poorly to coronavirus pneumonia (1,2). In previous pandemics caused by other coronaviruses, adverse outcomes were higher in pregnant women than in non-pregnant women, with a higher number of orotracheal intubations, renal failure, disseminated intravascular coagulation, a larger number of patients admitted to intensive care units (ICU), and higher mortality (3).

It is encouraging to see that the initial reports about this disease in pregnant women describe a mild clinical picture, with a $1 \%$ mortality in the United Kingdom (4). As for anesthetic management, current recommendations guide to the selection of neuraxial anesthesia instead of general anesthesia, in order to avoid aerosolization and healthcare staff contagion. At this point, very little is known about the repercussion of COVID-19 on maternal and neonatal outcomes, or cesarean sectionrelated complications.

The current literature on anesthetic management in this population is limited in terms of sample sizes and the quality of the studies. This work describes the clinical characteristics, the results of anesthetic and perioperative management, complications and neonatal outcomes in seroprevalent pregnant women for SARS-CoV-2 infection delivered by cesarean section.

\section{METHODS}

\section{Patients and diagnosis}

Observational, single-center study of pregnant women with serology of polymerase chain reaction (PCR) test for SARS-CoV-2, admitted to the National Maternal Perinatal Institute between 
April 1 and June 30, 2020. The protocol was submitted to the Research Methodology Evaluation Committee and the Ethics Committee of the National Maternal Perinatal Institute in Lima, Peru, for assessment and approval. The inclusion criteria were: pregnant women 18 years of age or older, with positive rapid or PCR test for SARS-CoV-2, undergoing cesarean section. The exclusion criteria were: pregnant women with a body mass index (BMI) of 40 or higher and/or fetal congenital malformations incompatible with life.

After approval of the protocol (Letter N. $\quad$ 048-2020-DG-N $015-O E A I D E / I N M P$, July 8,2020 ), the process of collecting the information was initiated using Google forms, with access restricted to the researchers only. The primary source for data collection were the clinical records of the individual patients. The epidemiological visualization window was 3 months and all patients who met the eligibility criteria were included in the analysis.

SARS-CoV-2 seroprevalence was determined by means of the qualitative rapid test in accordance with the reactivity criteria established by the Peruvian National Health Institute, and the interpretation was performed by the hospital clinical laboratory team. Samples of capillary blood were drawn using the SD BIOSENSOR Standard Q COVID-19 IgM/IgC Combo.

\section{Perioperative management}

The pregnant women were transferred from an isolation area to the operating theater, wearing surgical face masks. Two operating rooms were used exclusively for patients with reactive SARS-CoV-2. All the staff in contact with this group of patients in the operating room wore personal protective equipment against aerosols.

Afterobtaining the anesthesia informed consent, routine basic monitoring was established (non-invasive blood pressure, electrocardiography and pulse oximetry).
The technique of choice was neuraxial (spinal, combined spinal-epidural [CSE], epidural), provided maternal and fetal conditions allowed it.

\section{Neuraxial anesthesia technique}

L2-L3orL3-L4wasselectedas theintervertebral space for spinal, epidural or CSE puncture. A local infiltration with $2 \%$ lidocaine was used before insertion of the Tuohy N $\mathrm{N} .18$ epidural needle in the CSE and epidural techniques, while a a trial dose was administered when the epidural technique was used. For CSE and spinal anesthesia, a 4 3/4" and $3{ }^{1 / 2} 2^{\prime \prime} N^{\circ} 27$ needle was used, respectively, with a dose of 6-10 $\mathrm{mg}$ of $0.5 \%$ hyperbaric bupivacaine; lidocaine with $2 \%$ epinephrine was used for the epidural technique. Additionally, neuraxial opioids (fentanyl and morphine) were used as adjuncts.

Postanesthetic recovery took place in the same operating room where the procedure was performed, with discharge criteria being Bromage $=0$, Aldrete Scale 9 or higher, and absence of complications during the immediate postoperative period.

\section{Maternal and neonatal outcomes}

Data were extracted for all pregnant women with positive serology or PCR for SARS-CoV-2, including demographics, clinical characteristics (signs/symptoms, blood tests, ancillary tests such as rapid test or PCR for SARS-CoV-2), cesarean section categorization, vital signs at the beginning and the end of the surgery, type of anesthetic technique used, drugs used in anesthesia, use of vasopressors, Apgar score at 1 and 5 minutes, prophylaxis for nausea and vomiting, conversion to general anesthesia, operating time, estimated blood loss, use of uterotonics, use of blood products, use of tranexamic acid, intraoperative and postoperative complications, readmission to the operating room, and patient destination service.

\section{Statistical analysis}

Qualitative variables are presented as proportions or frequencies. The Shapiro Wilk test was used for quantitative variables in order to assess normal distribution. Results for variables with a normal distribution are expressed as means and standard deviations, while the results for variables without a normal distribution are expressed as medians and interquartile ranges. The STATA version 15 statistical software package was used for data and graph processing.

\section{RESULTS}

Clinical records of 107 pregnant women seroprevalent for SARS-CoV-2 (Figure 1) delivered by cesarean section were

Figure 1. Patient selection flow chart.

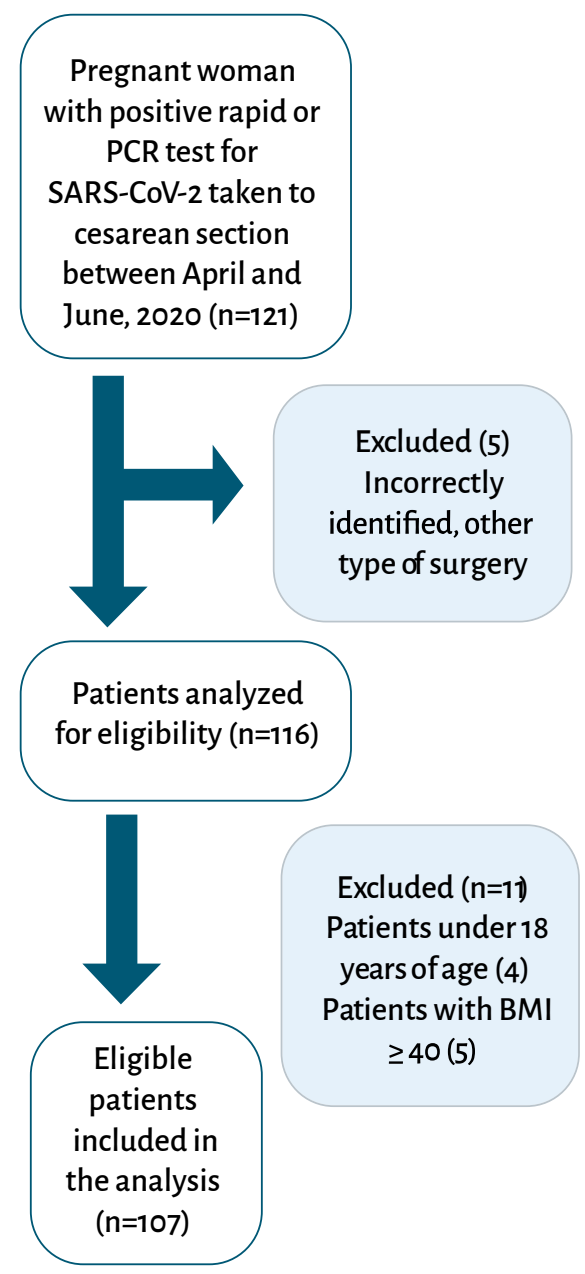

SOURCE: Authors. 
TABLE 1. Demographic and clinical characteristics of pregnant women with SARS-CoV-2.

\begin{tabular}{|c|c|c|}
\hline $\begin{array}{c}\text { Characteristic or } \\
\text { variable }\end{array}$ & $\begin{array}{c}\text { Number } \\
(\%)\end{array}$ & $\begin{array}{l}\text { Median } \\
\text { or [Mean] }\end{array}$ \\
\hline $\begin{array}{l}\text { Age in years } \\
(\square \pm S D)) \\
<20 \\
20-34 \\
>35\end{array}$ & $\begin{array}{c}8(7.48) \\
67(62.62) \\
32(29.91)\end{array}$ & $\begin{array}{c}{[30.21 \pm} \\
6.89]\end{array}$ \\
\hline $\begin{array}{c}\text { BMI. Me(IQR) } \\
\text { Normal } \\
\text { Overweight } \\
\text { Obesity I } \\
\text { Obesity II } \\
\text { Obesity III }\end{array}$ & $\begin{array}{l}12(11.21) \\
39(36.45) \\
31(28.97) \\
14(13.08) \\
11(10.28)\end{array}$ & $\begin{array}{l}30.2 \\
(26.8 . \\
34.7)\end{array}$ \\
\hline $\begin{array}{c}\text { Cestational age } \\
\text { in weeks Me(IQR) } \\
\text { Term } \\
\text { Preterm }\end{array}$ & $\begin{array}{l}85(79.44) \\
22(20.56)\end{array}$ & $39(37.40)$ \\
\hline $\begin{array}{l}\text { Symptoms prior to } \\
\text { hospitalization } \\
\text { Fever }(n) \\
\text { Cough }(n) \\
\text { Sore throat }(n) \\
\text { Dyspnea (n) } \\
\text { Castrointestinal } \\
\text { discomfort }(n)\end{array}$ & $\begin{array}{l}4 \\
1 \\
1 \\
1 \\
1\end{array}$ & \\
\hline $\begin{array}{c}\text { Ancillary tests } \\
\text { Rapid test } \\
\text { lgG+ e lgM+ } \\
\text { IgG + } \\
\text { IgM+ } \\
\text { Molecular test } \\
\text { (RT-PCR) } \\
\text { Positive } \\
\text { Negative }\end{array}$ & $\begin{array}{c}96(89.72) \\
6(5.61) \\
5(4.67)\end{array}$ & \\
\hline $\begin{array}{c}\text { Platelet count } \\
\mathrm{Me}(I Q R)\end{array}$ & & $\begin{array}{l}234.000 \\
(191.000 . \\
295.000)\end{array}$ \\
\hline $\begin{array}{l}\text { Leukocyte count } \\
\text { Me(IQR) }\end{array}$ & & $\begin{array}{r}9.700 \\
(8.300 . \\
11.500)\end{array}$ \\
\hline
\end{tabular}

$M_{e}$ : Median, IQR: Inter-quartile range, D: Mean, SD: Standard deviation n: number, BMI: body mass index

SOURCE: Authors.
TABle 2. Anesthesia technique and indication for cesarean section in SARSCoV-2 pregnant women.

\begin{tabular}{|c|c|}
\hline Characteristic or variable & Number(\%) \\
\hline $\begin{array}{l}\text { Reason for cesarean section } \\
\text { Cephalo-pelvic disproportion } \\
\text { Previous cesarean section } \\
\text { Non-reassuring fetal status } \\
\text { Hypertensive disorder } \\
\text { of pregnancy } \\
\text { Pneumonia } \\
\text { Other causes }\end{array}$ & $\begin{array}{l}20(18.69) \\
20(18.69) \\
14(13.08) \\
13(12.15) \\
2(1.87) \\
38(35.52)\end{array}$ \\
\hline $\begin{array}{l}\text { ASA physical condition } \\
\text { II } \\
\text { III }\end{array}$ & $\begin{array}{l}87(81.31) \\
20(18.69)\end{array}$ \\
\hline $\begin{array}{l}\text { Cesarean section classification } \\
\text { according to the Lucas classification } \\
\text { Category } 1 \\
\text { Category } 2 \\
\text { Category } 3 \\
\text { Category } 4\end{array}$ & $\begin{array}{c}6(5.61) \\
48(44.86) \\
47(43.93) \\
6(5.61)\end{array}$ \\
\hline $\begin{array}{l}\text { Nausea and vomiting prophylaxis } \\
\text { None } \\
\text { Dexamethasone } \\
\text { Ondansetron } \\
\text { Dexamethasone+ondansetron }\end{array}$ & $\begin{array}{c}4(3.74) \\
31(28.97) \\
24(22.43) \\
48(44.86)\end{array}$ \\
\hline $\begin{array}{l}\text { Oxygen therapy } \\
\text { Binasal cannula } \\
\text { Non-rebreather mask }\end{array}$ & $\begin{array}{l}1 \\
1\end{array}$ \\
\hline $\begin{array}{l}\text { Anesthetic technique } \\
\text { Neuraxial } \\
\text {-Spinal } \\
\text { - CSE } \\
\text { - Epidural }\end{array}$ & $\begin{array}{c}107(100) \\
100(93.5) \\
4(3.7) \\
3(2.8)\end{array}$ \\
\hline $\begin{array}{l}\text { Dose of } 0.5 \% \text { hyperbaric bupivacaine } \\
6 \mathrm{mg} \\
7 \mathrm{mg} \\
7,5 \mathrm{mg} \\
8 \mathrm{mg} \\
9 \mathrm{mg} \\
10 \mathrm{mg}\end{array}$ & $\begin{array}{c}1(0.96) \\
23(22.12) \\
5(4.81) \\
34(32.69) \\
24(23.08) \\
17(16.35)\end{array}$ \\
\hline $\begin{array}{l}\text { Use of neuraxial adjuncts } \\
\text { Fentanyl } \\
\text { Morphine }\end{array}$ & $\begin{array}{c}92(85.98) \\
101(94.39)\end{array}$ \\
\hline $\begin{array}{l}\text { Use of vasopressors } \\
\text { None } \\
\text { Prophylactic } \\
\text { Treatment }\end{array}$ & $\begin{array}{l}91(85.05) \\
8(7.48) \\
8(7.48)\end{array}$ \\
\hline $\begin{array}{l}\text { Anesthetic complications } \\
\text { None } \\
\text { Shivering } \\
\text { Pruritus }\end{array}$ & $\begin{array}{c}102(95.33) \\
4(3.74) \\
1(0.93)\end{array}$ \\
\hline
\end{tabular}

ASA: American Society of Anesthesiologist.

SOURCE: Authors. analyzed. Demographic, obstetrical and preoperative characteristics are shown in Table 1.

Of the 107 patients, 99 (92.52\%) were asymptomatic days before admission to the operating room and $8(7.48 \%)$ were symptomatic. Fever was the most common symptom, followed equally by sore throat, cough, dyspnea and gastrointestinal discomfort.

Diagnosis was made in all cases by means of qualitative anti SARS-CoV-2 $\lg M$ and IgC antibody measurements in capillary blood. In 96 (89.72\%) patients, tests were reactive for both antibodies, with only IgC reactivity in $6(5.61 \%)$ and IgM reactivity in 5 (4.67\%).

The anesthetic approach and indications for cesarean section in SARS$\mathrm{CoV}-2$ pregnant women are summarized in Table 2. The most frequent reasons for cesarean section were cephalo-pelvic disproportion (18.69\%), previous cesarean section $(18.69 \%)$, and non-reassuring fetal status (13.08\%). SARS-CoV-2 pneumonia as a reason for cesarean section was found in only $1.87 \%$ of cases. Prophylaxis for postoperative nausea and vomiting in the operating room (dexamethasone alone in $28.97 \%$, ondansentron alone in $22.43 \%$ and both medications in $44.86 \%$ ) was used in 103 (96.26\%) patients. As for oxygen therapy on admission to the operating room, only two patients required oxygen (binasal cannula in one case and bag mask in the other case).

The anesthetic technique at the start of the cesarean section was neuraxial in all cases; single-dose spinal anesthesia was used in 100 (93.5\%) patients and the CSE and epidural techniques were used in a lower percentage of cases (Figure 2). Motor and sensory block was achieved from T4-T5 to $\mathrm{S}_{4}-\mathrm{S}_{5}$ with all the techniques.

For the spinal block, the local anesthetic used was $0.5 \%$ hyperbaric bupivacaine at doses ranging between 6 and $10 \mathrm{mg}$. The most frequently used dose was 8 $\mathrm{mg}(32.69 \%)$, followed by the $9 \mathrm{mg}$ dose (23.08\%), as shown in Figure 3. Regarding neuraxial adjuvants, fentanyl was used in 
FIGURE 2. Neuraxial anesthesia techniques in pregnant women with SARS-CoV-2

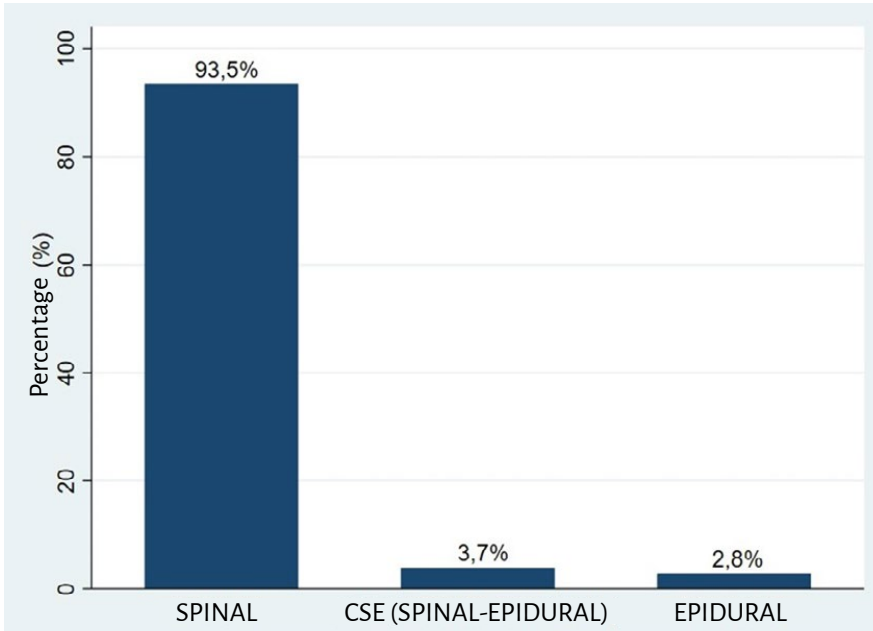

SOURCE: Authors.

FICURE 4. Vital signs before and after surgery.
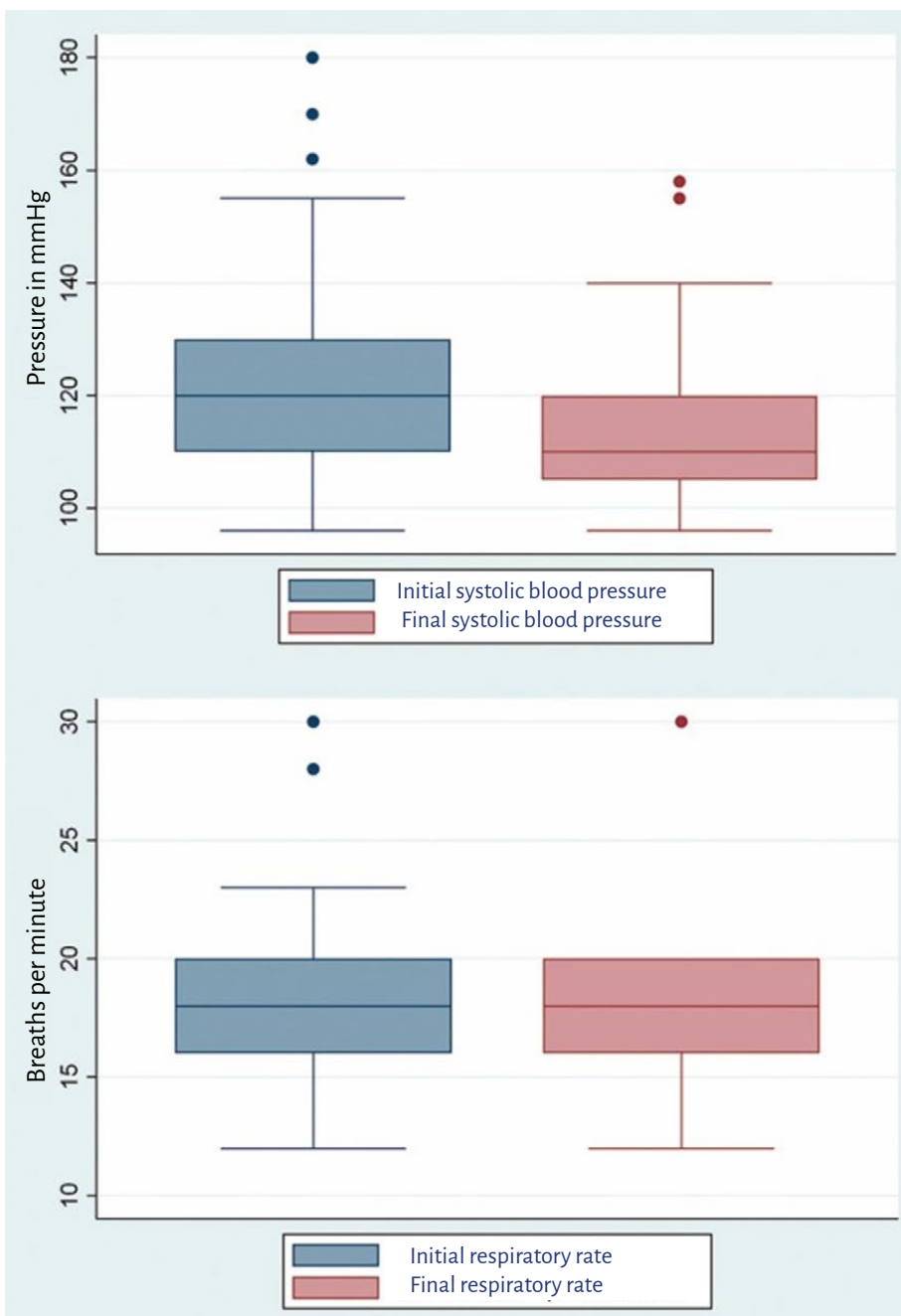
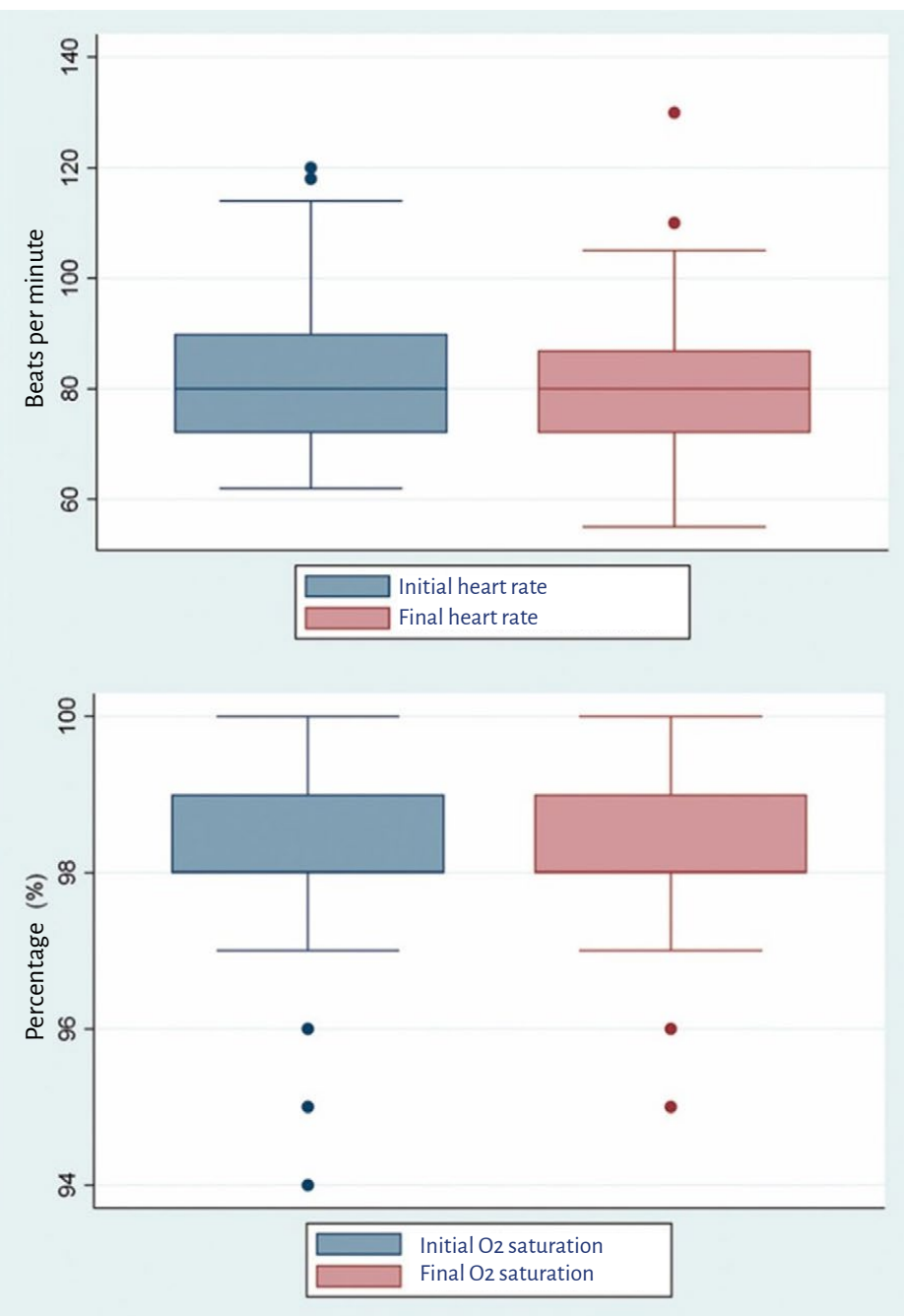

FIGURE 3. Hyperbaric bupivacaine dose in pregnant women with SARS-CoV-2.

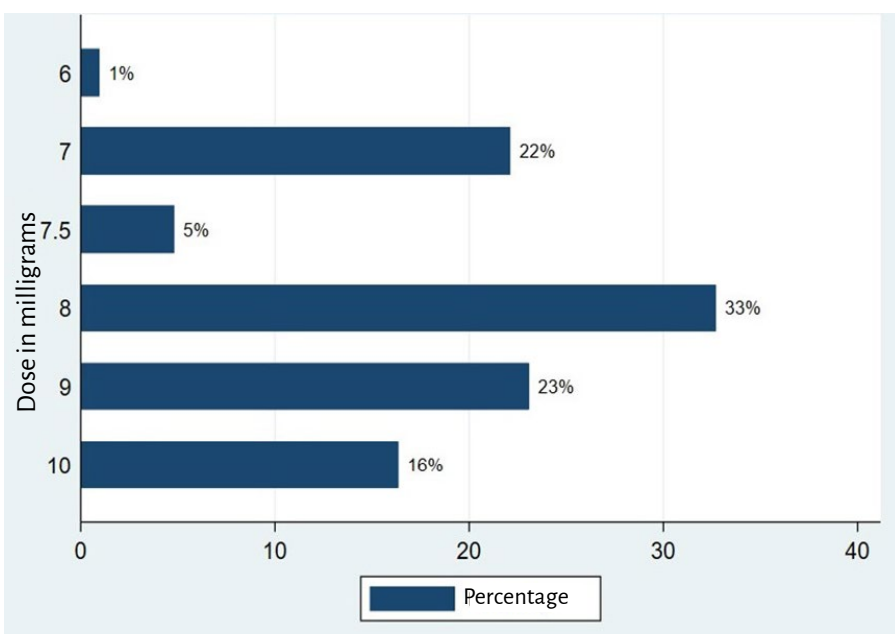

SOURCE: Authors.

SOURCE: Authors.

SOURCE: Authors. 
92 patients $(85.98 \%)$ and morphine was used in 101 (94.39\%). Likewise, 91 (85.05\%) patients did not receive vasopressors to prevent or treat the hypotension induced by the spinal block, $7.48 \%$ received prophylactic intravenous ethylephrine infusion, and rescue boluses were used in the same percentage of patients.

Medians as well as minimum and maximum vital sign values (heart rate, systolic blood pressure, oxygen saturation and respiratory rate) on arrival to, and exit from, the operating room are shown in Figure 4 , highlighting minimum variation between values.

Table 3 shows the relationship with surgical and neonatal outcomes. Median surgical time was 42 minutes (IQR 3050 min). Median APGAR scores at 1 and 5 minutes after birth were 8 and 9 , respectively.

There was no intraoperative need to convert to general anesthesia; conversion to hysterectomy was required only in 3 patients and 2 of them needed blood product transfusions. Tranexamic acid was used in 5 patients $(4.67 \%)$ and no thromboembolic events had been reported up until 72 hours after surgery. Only 1 patient received preoperative pharmacological thromboprophylaxis.

Two patients developed intraoperative pneumonia and one of them was transferred to the ICU after the surgery.

TABLE 3. Surgical and neonatal outcomes in SARS-CoV-2 pregnant women.

\begin{tabular}{|c|c|c|}
\hline Characteristic or Variable & Number (\%) & $\begin{array}{c}\text { Median } \\
\text { (IQR) }\end{array}$ \\
\hline Surgical time in minutes Me (IQR) & & $42(30.50)$ \\
\hline \multicolumn{3}{|l|}{ Blood loss } \\
\hline$>1000 \mathrm{ml}$ & $2(2.8)$ & \\
\hline$<1000 \mathrm{ml}$ & $104(97.19)$ & \\
\hline \multicolumn{3}{|l|}{ Use of uterutonic agents } \\
\hline Oxytocin & $37(34.58)$ & \\
\hline Oxytocin+ergometrine & $31(28.97)$ & \\
\hline Carbetocin+ergometrine & $13(12.15)$ & \\
\hline Oxytocin+ergometrine+misoprostol & $12(11.21)$ & \\
\hline \multicolumn{3}{|l|}{ Newborn Apgar score Me(IQR) } \\
\hline 1 minute & & $8(8.8)$ \\
\hline 5 minutes & & $9(9.9)$ \\
\hline \multicolumn{3}{|l|}{ Patient destination } \\
\hline Inpatient ward & $105(98.13)$ & \\
\hline Intensive care unit & $2(1.77)$ & \\
\hline \multicolumn{3}{|l|}{ Obstetric complications } \\
\hline Uterine hypotonia & $14(13.08)$ & \\
\hline Conversion to hysterectomy & $3(2.80)$ & \\
\hline Use of blood products & $3(2.80)$ & \\
\hline Use of tranexamic acid & $2(1.87)$ & \\
\hline
\end{tabular}

Moreover, 14 patients had hypotonia-atony and 3 of them underwent hysterectomy. One of these three patients was transferred to the ICU at the end of the surgical reintervention. The remaining 105 (98.13\%) patients were transferred to hospitalization at the end of the post-anesthesia recovery period. No deaths had occurred up until the third postoperative day.

\section{DISCUSSION}

This work found that pregnant women were asymptomatic in $92.52 \%$ of cases, while $7.48 \%$ showed mild symptoms before hospitalization, with fever being present in the highest proportion. Gao et al. (5) report that symptoms such as fever (51\%) and cough $(31 \%)$ in pregnant women with COVID-19 were lower than in non-pregnant women ( $91 \%$ and $67 \%$, respectively), which could we attributed to changes in the immune system of the pregnant women.

Symptoms prior to hospitalization and the rapid antibody test for SARS-CoV-2 were considered in the diagnosis of SARSCoV-2 infection in this study. Oropharyngeal swab for RT-PCR was done in 4 of the 8 symptomatic patients with a positive rapid test, with 1 being reactive.

At the beginning of the pandemic, similar to several other countries in Latin America, the Ministry of Health in our country considered that the diagnosis should be based on the epidemiological background and individual patient characteristics, and that it should be confirmed with laboratory tests such as the rapid test for SARS-CoV-2 antibodies or RT-PCR.

In their study of SARS-CoV-2 prevalence carried out over a similar period of time, Flannery et al. (6) found in 1,293 pregnant women in Philadelphia that out of 72 seropositive women, only 46 were reactive on RT-PCR, while out of 1,037 seronegative women, only 18 were reactive on RT-PCR. Hence the need for further infection time studies between seropositivity and positive RT-PCR of SARS-CoV-2 infection in pregnant women. Likewise, Vidal et al. (7) report 
that both tests need to be complementary because of their diagnostic ability as a function of infection time.

Regarding the reason for cesarean section, it was found that the most frequent causes were cephalo-pelvic disproportion, previous cesarean section and nonreassuring fetal status. Similar results were described by Cao et al. (8), where 2 out of 8 patients $(25 \%)$ required emergency cesarean section due to non-reassuring fetal status and the other 6 included diagnoses such as previous cesarean section, pre-eclampsia, among others. Unlike the case series by Chen et al.(9) in which only $18 \%$ (3 pregnant women out of 17) required emergency cesarean section.

In this work, SARS-CoV-2 pneumonia was present in $1.87 \%$ of cases, resulting in an indication for cesarean section. This is in contrast with the study by Turan et al. (10), in which SARS-CoV-2 infection was the reason for cesarean section in $49.6 \%$ of preterm deliveries despite the absence of maternal or fetal risk. In $65.7 \%$ of term deliveries, COVID-29 was the indication for cesarean section. These figures show that the differences found were due to the fact that the SARS-CoV-2 infection was considered an indication for cesarean section, which was not the case in our study.

The anesthetic technique at the initiation of the cesarean section was neuraxial in all cases, with the single-dose technique used in the vast majority of patients. In a large case series, Zhong et al. (11) found that spinal anesthesia was used safely in $91.84 \%$ of their patients. In the study by Chen et al. (9), $18 \%$ of the pregnant women received general anesthesia, and $82 \%$ received anesthesia through epidural catheter, while in the study by Yue et al.(12), the CSE technique was used in 30 patioents, none of whom required general anesthesia. The difference with the study by Chen was that general anesthesia was selected due to fetal compromise that required immediate anesthetic approach. These results show that the neuraxial technique was safe in these patients.

Regarding the use of uterotonics, Bauer et al. (13) published in a review article the recommendation on the use of oxytocin or oxytocin derivatives (carbetocin) as first line drug and ergometrine as second line agent in these patients; in this study, oxytocin or carbetocin were used in $100 \%$ of patients as first-line drug, while misoprostol was used only in $7.5 \%$ of patients who needed a second line agent. As for costs, in a case report at the beginning of the pandemic, Landau et al. (14) described bronchospasm as a complication related to the use of prostaglandins (misoprostol), requiring airway management or orotracheal intubation and increasing the risk of infection for the attending staff.

Postpartum bleeding is one of the main causes of morbidity and mortality in pregnant women, and cannot be neglected when analyzing the impact of the pandemic. In relation to estimated bleeding during cesarean section, Yue et al. (12) published a study on the anesthetic management of 30 patients with confirmed or suspected COVID-19 infection in which they found greater blood loss among confirmed cases $(334,7 \pm 63.3)$, than in suspected cases $(293,8 \pm 25)$; although this difference in not clinically relevant, estimated bleeding in this study was very similar $(500 \mathrm{~mL}[\mathrm{IQR}$ $500,600]$ ).

Turan et al. (10) found 6 cases of postpartum bleeding with more than $1,000 \mathrm{~mL}$ of blood loss during cesarean section in 637 patients (0.9\%). Three of them had severe COVID-19 infection, one of them developed coagulopathy, while the remaining two showed mild symptoms. This study found some degree of uterine hypotonia in 14 patients during surgery, but only 3 patients $(2.8 \%)$ had bleeding of more than $1,000 \mathrm{~mL}$. Of the three patients with postpartum bleeding, two were morbidly obese and were of advanced maternal age (44 years), while the third patient had dyspnea and required oxygen supplementation on arrival at the operating room. Blood products and tranexamic acid were used in two patients and total abdominal hysterectomy was performed in three patients.

The use of nausea and vomiting prophylaxis in these patients is crucial due to the risk of contamination during the intraoperative and immediate postoperative periods; this work found that $96.26 \%$ of the patients received some form of pharmacological prophylaxis for this end.

In various publications, one of the main controversies has to do with the relationship between SARS-CoV-2 infection in the pregnant woman and maternal death. Zaigham et al.(15), in a systematic review of 18 articles including a total of 108 pregnant women (very similar number to that of this work), did not report any maternal deaths. In a more extensive review of 63 observational studies with a total of 637 patients, the reported incidence was $1.6 \%$ (10 maternal deaths), of which 2 patients were older than 40 years of age, while another 2 were obese and diabetic (10). A more extensive meta-analysis published in September described an even lower incidence of $0.1 \%$ (73 maternal deaths out of 11,580 pregnant women with COVID-19 infection) (16). This work did not find any cases of maternal death in the 72 hours following cesarean section, albeit with no follow-up beyond that time.

One of the signs of severity of the infection is the development of pneumonia requiring oxygen supplementation. In their review, Zaigham et al. (15) found that 2 out of 108 patients (1.85\%) who developed acute respiratory distress syndrome required orotraheal intubation and mechanical ventilation. In this work, two patients developed pneumonia during the perioperative period and required oxygen supplementation, and one of them needed to be transferred to the intensive care unit postoperatively. Those two patients were under 35 years of age and were delivered preterm, at 32 and 35 weeks of gestational age.

Although pregnancy is known to be a hypercoagulable state characterized by an elevation of prothrombotic factors, no increased risk of thromboembolic events has yet been shown in the current literature of pregnant patients admitted with COVID-19 when compared with nonpregnant patients infected by this same 
virus (17). No thromboembolic events were found in this work up until the third postoperative day. Nonetheless, risk stratification, especially in this group of patients, is of the utmost importance.

Outcomes for the newborns are a source of concern in this setting. In their review, Turan et al. (10) found low Apgar scores (below 7 at 1 and 5 minutes of life) in 6 out of 361 neonates $(1.7 \%)$ reported across 29 studies. They were all preterm babies delivered because of loss of fetal wellbeing secondary to COVID-19 compromise in the mothers. In this review, we found 5 neonates (4.7\%) with Apgar scores below 8 at 5 minutes of life, but two of them had a diagnosis of fetal malformations before admission to the operating room, while the reason for cesarean section in the remaining four cases were equally distributed between non-reassuring fetal status and cephalo-pelvic disproportion. They were are all term babies and only one of the mothers had respiratory distress requiring oxygen. The other mothers did not have any symptoms of the disease.

The main strength of this work is sample size when compared with other world studies on perioperative anesthetic management. Additional strengths include the analysis based on current evidence of clinical characteristics, perioperative anesthetic management and complications in pregnant women with serological identification of SARS-CoV-2 infection.

The main weaknesses include time, the use of convenience sampling and the small number or molecular RT-PCR tests available. As far as the latter is concerned, we are aware that the reference standard recommended by the WHO for the diagnosis of SARS-CoV-2 infection is realtime reverse transcription- polymerase chain reaction (18).

In April 2020, Vidal-Anzardo et al. published a research study comparing rapid serological tests with molecular tests, used in Peru in field conditions, in terms of diagnostic yield, sensitivity and specificity. For serological tests, sensitivity was $43.8 \%$ (95\% Cl [19.8-70.1]), which increased gradually over time, with $\% \%$ identification in the first week, $33.3 \%$ in the second week and $50 \%$ beyond that time, while specificity was $98.9 \%(95 \% \mathrm{Cl}[94.0-100])$ (7). For the molecular RT-PCR test, sensitivity was $69.2 \%$ in the first week, but dropped to $25 \%$ by the second week and down to $13 \%$ beyond that time (5).

Consequently, the serological test becomes important as a complement to the molecular test after the second and third week of the infection.

Despite the challenges described above, it may be concluded from this study that the majority of pregnant women with SARSCoV- 2 infection are asymptomatic and that neuraxial anesthesia, including spinal, combined spinal-epidural and epidural, were found to be safe techniques for these patients and their newborn babies.

\section{ETHICAL RESPONSIBILITIES}

\section{Ethics committee endorsement}

This study was approved by the Ethics Committee of the National Maternal Perinatal Institute during a meeting held on July 8,2020 , as evidenced in Letter $\mathrm{N}^{\circ}$

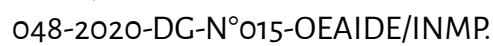

\section{Human and animal protection}

The authors declare that no human or animal experiments were carried out as part of this research.

\section{Data confidentiality}

The authors declare that they have followed the protocols of their institution on patient data disclosure.

\section{Right to privacy and informed consent}

The authors declare that no patient data appear in this paper.

\section{ACKNOWLEDGEMENTS}

\section{Authors' contributions}

MEHB: Study planning, data collection, interpretation of the results, initial writing of the manuscript.

MLCL, ÁRMG, JGVR: Data collection, interpretation of the results, initial writing of the manuscript.

\section{Assistance for the study}

The authors declare having received methodological and statistical assistance from the National Maternal Perinatal Institute research unit.

\section{Funding and sponsorship}

Funding for this research came only from the authors.

\section{Conflict of interest}

The authors have no disclosures to make.

\section{Presentations}

None declared.

\section{Appreciation}

The authors are grateful to the Research Unit and the Statistics Office of the National Maternal Perinatal Institute.

\section{REFERENCES}

1. Ashokka B, Loh MH, Tan CH, et al. Care of the pregnant woman with coronavirus disease 2019 in labor and delivery: anesthesia, emergency cesarean delivery, differential diagnosis in the acutely ill parturient, care of the newborn, and protection of the healthcare personnel. Am J Obstet Gynecol. 
2020;223(1):66-74. doi: http://www.doi.org/10.1016/j.ajog.2020.04.005

2. Omer S, Ali S, Din Babar Z. Preventive measures and management of COVID-19 in pregnancy. Drugs Ther Perspect. 2020;1-4. doi: http:// www.doi.org/10.1007/s40267-020-00725-x

3. Knight $M$, Bunch $K$, Vousden $N$, Morris $E$, Simpson N, Gale C, et al. Characteristics and outcomes of pregnant women admitted to hospital with confirmed SARS-CoV-2 infection in UK: national population based cohort study. BM]. 2020;369:m2107. doi: http://www. doi.org/10.1136/bmj.m2107

4. Khalil A, Kalafat E, Benlioglu, O’Brien P, Morris E, Draycott T, et al. SARS-CoV-2 infection in pregnancy: A systematic review and meta-analysis of clinical features and pregnancy outcomes. E Clinical Medicine. 2020;25. doi: http://www.doi.org/10.1016/j. eclinm.2020.100446

5. Gao Yj, Ye L, Zhang Js, Yin Yx, Liu M, Yu H, et al. Clinical features and outcomes of pregnant women with COVID-19: a systematic review and meta-analysis. BMC Infectious Diseases. 2020;20(1):564. doi: http://www.doi. org/10.1186/s12879-020-05274-2

6. Flannery DD, Couma S, Dhudasia MB, Mukhopadhyay S, Pfeifer MR, Woodford EC, et al. SARS-CoV-2 seroprevalence among parturient women. MedRxiv Prepr Serv Health Sci. 2020. doi: http://www.doi. org/10.1101/2020.07.08.20149179

7. Vidal-Anzardo M, Solis C, Solari L, Minaya G, Ayala-Quintanilla B, Astete-Cornejo ], et al. Evaluación en condiciones de campo de una prueba rápida para detección de anticuerpos IgM e IgC contra SARS-CoV-2. Rev Peru Med Exp Salud Pública. 2020;37(2):203-9. doi: http:// www.doi.org/10.17843/rpmesp.2020.372.5534

8. Cao D, Yina H, Chena, J, Tanga F, Penga M, Lib R, et al. Clinical analysis of ten pregnant women with COVID-19 in Wuhan, China: A retrospective study. Int ] of Infect Dis. 2020;95:294-300. doi: https://doi.org/10.1016/j.ijid.2020.04.047

9. Chen R, Zhang Y, Huang L, et al. Safety and efficacy of different anesthetic regimens for parturients with COVID-19 undergoing Cesarean delivery: a case series of 17 patients. Can ] Anaesth. 2020;67(6):655-63. doi: http://www. doi.org/10.1007/s12630-020-01630-7

10. Turan O, Hakim A, Dashraath P, Jeslyn WJL, Wright A, Abdul-Kadir R. Clinical characteristics, prognostic factors, and maternal and neonatal outcomes of SARS-CoV-2 infection among hospitalized pregnant women: A systematic review. Int ] Cynaecol Obstet. 2020;151(1):7-16. doi: http://www.doi. org/10.1002/ijgo.13329

11.Zhong Q, Liu YY, Luo Q, Zou YF, Jiang HX, Li $\mathrm{H}$, et al. Spinal anaesthesia for patients with coronavirus disease 2019 and possible transmission rates in anaesthetists: retrospective, single-centre, observational cohort study. $\mathrm{Br}$ ] Anaesth. 2020;124(6):670-5. doi: http://www. doi.org/10.1016/j.bja.2020.03.007

12. Yue L, Han L, Li Q, Zhong M, Wang J, Wan Z, et al. Anesthesia and infection control in cesarean section of pregnant women with $\mathrm{CO}$ VID-19 infection: A descriptive study. J Clin Anesth. 2020;66:109908. doi: http://www.doi. org/10.1016/j.jclinane.2020.109908
13. Bauer ME, Bernstein K, Dinges E, et al. Obstetric anesthesia during the COVID-19 pandemic. Anesth Analg. 2020;131(1):7-15. doi: http:// www.doi.org/10.1213/ANE.0000000000004856

14. Landau R, Bernstein K, Mhyre ]. Lessons learned from first COVID-19 cases in the United States. Anesth Analg. 2020;131(1):e25-6. doi: http://www.doi. org/10.1213/ANE.0000000000004840.

15. Zaigham M, Andersson O. Maternal and perinatal outcomes with COVID-19: A systematic review of 108 pregnancies. Acta Obstet Gynecol Scand. 2020;99(7):823-9. doi: http://www. doi.org/10.1111/aogs.13867.

16. Allotey ], Stallings E, Bonet M, Yap M, Chatterjee $\mathrm{S}$, Kew $\mathrm{T}$, et al. Clinical manifestations, risk factors, and maternal and perinatal outcomes of coronavirus disease 2019 in pregnancy: living systematic review and meta-analysis. BM] 2020;370:m3320. doi: http:// www.doi.org/10.1136/bmj.m3320

17. D'Souza R, Malhamé I, Teshler L, Acharya G, Hunt B], McLintock C. A critical review of the pathophysiology of thrombotic complications and clinical practice recommendations for thromboprophylaxis in pregnant patients with COVID-19. Acta Obstet Gynecol Scand. 2020;99(9):1110-20. doi: http://www.doi. org/10.1111/aogs.13962

18. PAHO. Laboratory guidelines for the detection and diagnosis of COVID-19 virus infection [Internet]. 2020 [citado: 2021 feb. 5]. Disponible en: https://iris.paho.org/bitstream/ handle/10665.2/52458/PAHOIMSPHECOVID-19200038_eng.pdf?sequence $=1 \&$ is Allowed $=\mathrm{y}$ 